Biol. Neonat. 1967;11:I-IV

\title{
Contents, Vol. 11, 1967
}

\section{Index}

Ainsworth, Patricia : vide Ditchburn, R. K.

Anderson, T. A.: vide Geber, W. F.

Baig, Ayesha R. and Telford, Ira R.: Histologícal Studies of the Placenta and Utetus of the Normal and the Resorbing Rat Fetus 137

Barta, E.: vide Breuer, E

Birch, H.G.: vide Cravioto, J

Boréus, L.O.: Pharmacology of the Human Fetus: Dose-Effect Relationships for Acetylcholine During Ontogenesis 328

Breuer, E.; Barta, E.; Pappová, E. and Zlatos, L.: Developmental Changes of Myocardial Metabolism. I. Peculiarities of Cardiac Carbohydrate Meta bolism in the Early Postnatal Period in Dogs 367

Britton, H. G.; Nixon, D.A. and Wright, G.H.: The Effects of Acute Hypoxia on the Sheep Foetus and Some Observations on Recovery from Hypoxia 277 Cravioto, J.; Licardie, E. R.; Montiel, R. and Birch, H. G.: Motor and Adap tive Development of Premature Infants from a Preindustrial Setting during the First Year of Life 151

Czajka, D. M.: vide Miller, S.A.

Davies, Pamela A.: vide Ditchburn, R. K.

Ditchburn, R. K.; Wilkinson, R.H.; Davies, Pamela A. and Ainsworth,

Patricia : Plasma Glucose Levels in Infants Weighing $2500 \mathrm{~g}$ and Less Fed Immediately after Birth with Breast Milk

Drahota, Z.: vide Melichar, V.

Dreyfus-Brisac, C.: vide Monod, N.

Eliet-Flescher, J.: vide Monod, N.

Esterly, J.R.: Histochemícal Demonstration of Intestinal Glycosidases in the Neonatal Rat 378

Fox, H.: The Significance of Placental Infarction in Perinatal Morbidity and Mortality 87

Geber, W. F. and Anderson, T. A.: Abnormal Fetal Growth in the Albino Rat and Rabbit Induced by Maternal Stress 209

Grant, K.D.: vide Prechtl, H.F. R.

Hahn, P.: vide Melichar, V.

Heringová, A.: vide Jirsová, V.

Janovský, M.: Martínek, J. and Stanincová, V.: The Distribution of Sodium, Chloride and Fluid in the Body of Young Infants with Increased Intake of $\mathrm{NaCl} 261$ 
Janovský, M.; Martínek, J.; Stanincová, V. and Slechtová, R.: The Excretion of Total Solutes, Sodium, Potassium and Chloride in Newborn Infants after a Water Load 176

Jirsa, M.: vide Jirsová, V.

Jirsová, V.; Jirsa, M.; Heringová, A.; Koldovský, O. and Weirichová, J.:

The Use and Possible Diagnostic Significance of Sephadex Gel Filtration of Serum from Icteric Newborn 204

Koldovský, O.: vide Jirsová, V.

Index

Kraus, M.; Krecek, J. and Popp, M.: The Development of Aldosterone Production by the Adrenal Glands of Normally and Prematurely Weaned Rats . 338

Krecek, J.: vide Kraus, M.

Lenard, H.G.: vide Prechtl, H.F.R.

Licardie, E.R.: vide Cravioto, J.

Martin, Liliane: vide Rizzuto, N.

Martínek, J.: vide Janovský, M.

Mathews, J. and Partington, M.W.: Tyrosine Load Tests in Newborn Babies 273

Mathis, R.: vide Wagner, M.

Melichar, V.; Drahota, Z. and Hahn, P.: Ketone Bodies in the Blood of Full

Term Newborns, Premature and Dysmature Infants and Infants of Diabetic

Mothers 23

Melichar, V. and Wolf, H.: Postnatal Changes in the Blood Serum Content of Glycerol and Free Fatty Acids in Premature Infants. Influence of Hypo

thermia and of Respiratory Distress

50

Miller, Faith S.: vide Zakhary, Rizkalla

Miller, J.A., Jr.: vide Zakhary, Rizkalla

Miller, S.A. and Czajka, D.M.: The Influence of Dietary Osmolarity on Sur

vival in the Neonatal Rat 197

Milley, P. S.: Vagotomy and Pulmonary Hyaline Membranes in the Newborn

Rat 186

Milley, P. S.: The Pulmonary Effects of Recurrent Laryngeal Nerve Sectioning in the Newborn Rat 302

Monod, N.; Eliet-Flescher, J. and Dreyfus-Brisac, C.: Le sommeil du nouveauné et du premature 216

Montiel, R.: vide Cravioto, J.

Naeye, R.L.: Prenatal Organ and Cellular Growth with Various Chromosomal

Disorders 248

Nixon, D.A.: vide Britton, H.G.

Ottelin, A.-M.: vide Zilliacus, $\mathrm{H}$.

Pappová, E.: vide Breuer, E.

Partington, M.W.: vide Mathews, J.

Pickett, L. K.: vide Spencer, R. P.

Polgar, G.: Opposing Forces to Breathing in Newborn Infants

Popp, M.: vide Kraus, M. 
Prechtl, H.F.R.; Vlach, V.; Lenard, H.G. and Grant, K.D.: Exteroceptive and Tendon Reflexes in Various Behavioural States in the Newborn

Infant 159

Raiha, N.: vide Stern, L.

Rizzuto, N. et Martin, Liliane: Le problème de Гencéphalopathie foetale

kystique survenant au cours du deuxième tiers de la grossesse $\quad 115$

Rockoff, Maxine, L.: vide Spencer, R. P.

Shanklin, D. R. and Sotelo-Avila, C.: The Effects of Components of Vagotomy

on the Lung and the Effects of Anesthesia on Vagotomy Induced Lung

Change

61

Slechtová, R.: vide Janovský, M.

Sotelo-Avila, C.: vide Shanklin, D.R.

Sourkes, Th. L.: vide Stern, L.

Spencer, R. P.; Rockoff, Maxine L.; Pickett, L. K. and Talner, N. S.: Estima

tion of Cross Circulation Dynamics in Conjoined Twins 392

Stanincová, V.: vide Janovský, M.

Stave, U.: Age-Dependent Changes of Metabolism. III. The Effect of Prolonged

Hypoxia upon Tissue Enzyme Activities of Newborn and Adult Rabbits. . 310

Index

Stern, L.; Sourkes, Th.L. and Raiha, N.: The Role of the Adrenal Medulla in

the Hypoglycemia of Foetal Malnutrition 129

Talner, N.S.: vide Spencer, R. P.

Telford, Ira R.: vide Baig, Ayesha, R.

Terplan, K.L.: Histopathologic Brain Changes in 1152 Cases of the Perinatal and

Early Infancy Period 348

Vlach, V.: vide Prechtl, H.F.R.

Wagner, G.: vide Wagner, $M$.

Wagner, M.; Wagner, G. and Mathis, R.: Measurements of Nutritional Status

of Newborn Infants 106

Weirichová, J.: vide Jirsová, V.

Wilkinson, R.H.: vide Ditchburn, R.K.

Wolf, H.: vide Melichar, V.

Wright, G.H.: vide Britton, H.G.

Zakhary, Rizkalla; Miller, J.A., Jr. and Miller, Faith S.: Hypothermia,

Asphyxia and Brain Carbohydrates in Newborn Puppies 36

Zilliacus, H. and Ottelin, A.-M.: Haemoglobins in the Blood of Human

Embryos $\quad 389$

Zlato§, L.: vide Breuer, E.

Buchbesprechungen-Book Rewievs-Livres Nouveaux 128, 399

All rights, including that of translation into other languages, reserved.

Photomechanic reproduction (photocopy, microcopy) of this volume or parts thereof without

special permission of the publishers is prohibited

(C)

Copyright 1967 by S. Karger AG, Basel

Printed in Switzerland by Buchdruckerei Fritz Pochon-Jent AG, Bern

Cliches: Aberegg-Steiner, Bern 